\title{
Economical nitrogen dose for production of irrigated naturally colored cotton in the semi-arid region
}

\author{
Francilene de L. Tartaglia ${ }^{1}$, Allysson P. dos Santos ${ }^{2}$, Almir R. E. de Souza ${ }^{1}$, Manoel G. dos Santos ${ }^{2}$,
} Lindomar M. da Silveira² \& Aurélio P. Barros Júnior ${ }^{2}$

${ }^{1}$ Instituto Federal de Educação, Ciência e Tecnologia de Alagoas/Campus Piranhas. Piranhas, AL, Brasil. E-mail: francilene.tartaglia@ifal.edu.br - ORCID: 0000-0001-6023-0033; almir.souza@ifal.edu.br - ORCID: 0000-0002-9266-5063

${ }^{2}$ Universidade Federal Rural do Semi-Árido/Centro de Ciências Agrárias/Departamento de Ciências Agronômicas e Florestais/Programa de Pós-Graduação em Fitotecnia. Mossoró, RN, Brasil. E-mail: allyssoneng@gmail.com - ORCID: 0000-0002-2224-241X; manoel.galdino5@gmail.com - ORCID: 0000-0003-49725849; lindomarmaria@ufersa.edu.br - ORCID: 0000-0001-9719-7417; aurelio.barros@ufersa.edu.br (Corresponding author) - ORCID: 0000-0002-6983-8245

\begin{abstract}
Determining the economical dose of nitrogen $(\mathrm{N})$ for colored cotton can increase yield and income of farmers. The experiment was carried out under field conditions at the Experimental Farm of the Universidade Federal Rural do Semi-Árido, in the years 2016 and 2017. The objective was to determine the economical $\mathrm{N}$ dose for four colored cotton cultivars. The experimental design was in randomized blocks, with split plots and four repetitions. Five $\mathrm{N}$ doses $\left(0,50,100,150\right.$ and $\left.200 \mathrm{~kg} \mathrm{ha}^{-1}\right)$ were randomized in the main plots and four colored cotton cultivars (BRS Safira, BRS Rubi, BRS Topázio and BRS Verde) were randomized in the subplots. The characteristics evaluated were seed cotton yield, cotton fiber yield, $\mathrm{N}$ concentration in leaf tissue, technical dose and economical dose of N. Higher yield of naturally colored cotton can be obtained using the economical doses of $140 \mathrm{~kg} \mathrm{ha}^{-1} \mathrm{~N}$ for cultivars BRS Rubi and BRS Verde, $150 \mathrm{~kg} \mathrm{ha}^{-1} \mathrm{~N}$ for BRS Topázio and $160 \mathrm{~kg} \mathrm{ha}^{-1} \mathrm{~N}$ for BRS Safira. Highest yield was achieved with the cultivar BRS Topázio and lowest with the cultivar BRS Verde.
\end{abstract}

Key words: Gossypium hirsutum L., cultivars, fiber yield

\section{Dose econômica de nitrogênio para produção de algodão naturalmente colorido irrigado na região semiárida}

RESUMO: A determinação da dose econômica de nitrogênio para o algodoeiro colorido pode aumentar a produtividade e a renda dos agricultores. O experimento foi realizado em condição de campo na Fazenda Experimental da Universidade Federal Rural do Semi-Árido, nos anos de 2016 e 2017. O objetivo foi determinar a dose econômica de nitrogênio para quatro cultivares de algodão colorido. O delineamento experimental foi em blocos casualizados, com parcelas subdivididas e quatro repetições. Nas parcelas principais casualizaramse cinco doses de nitrogênio $\left(0,50,100,150\right.$ e $\left.200 \mathrm{~kg} \mathrm{ha}^{-1}\right)$ e nas subparcelas, quatro cultivares de algodão colorido (BRS Safira, BRS Rubi, BRS Topázio e BRS Verde). As características avaliadas foram produtividade de algodão em caroço, produtividade de fibra de algodão, teor de nitrogênio no tecido foliar, dose técnica e dose econômica de nitrogênio. Maior produtividade de algodão naturalmente colorido pode ser obtida utilizando as doses econômicas de $140 \mathrm{~kg} \mathrm{ha}^{-1} \mathrm{~N}$ para as cultivares BRS Rubi e BRS Verde, $150 \mathrm{~kg} \mathrm{ha}^{-1} \mathrm{~N}$ para BRS Topázio e $160 \mathrm{~kg} \mathrm{ha}^{-1} \mathrm{~N}$ para a BRS Safira. Maior produtividade foi alcançada com a cultivar BRS Topázio e menor, com a cultivar BRS Verde.

Palavras-chave: Gossypium hirsutum L., cultivares, produtividade de fibra 


\section{INTRODUCTION}

Cotton (Gossypium hirsutum L.) with naturally colored fiber is grown in the Brazilian semi-arid region. Its cultivation is carried out by family labor, making it of great social and economic importance for the region (CONAB, 2013). In addition, it has environmental importance, as it dispenses with the dyeing stage and requires lower water consumption in its processing (Queiroga et al., 2008; Peixoto et al., 2013).

Colored cotton cultivation in the Northeast region does not employ important cultivation techniques, such as chemical fertilization and irrigation, which leads to low yield (Queiroga et al., 2008; CONAB, 2013). One of the ways to increase yield is to use chemical fertilizers, including nitrogen (Lima et al., 2017). Nitrogen is essential to increase cotton fiber yield and quality (Dong et al., 2010; Reis Junior et al., 2012; Devkota et al., 2013; Stamatiadis et al., 2016), but the cultivars have different nitrogen requirements to achieve maximum yield (Ferreira \& Carvalho, 2005; Araújo et al., 2013; Du et al., 2016). Thus, the ideal is to use specific doses of nitrogen for each cultivar.

For the cultivars BRS Verde and BRS 200 Marrom, the maximum fiber yields were obtained at $\mathrm{N}$ doses of 240 and $300 \mathrm{~kg} \mathrm{ha}^{-1}$, respectively (Lima et al., 2006; Alves et al., 2009). These studies, however, considered only the dose of physical efficiency (technical dose of $\mathrm{N}$ ), disregarding the selling price of cotton and the cost of nitrogen fertilizer.

To obtain maximum economic return, it is necessary to determine the dose of maximum economic efficiency (Resende \& Costa, 2014). Doses above the economical dose do not bring economic return for the producer. Thus, the objective of this study was to determine the economical dose of nitrogen for four colored cotton cultivars in northeastern Brazil and the most responsive cultivar to nitrogen fertilization.

\section{Material ANd Methods}

The experiment was carried out under field conditions at the Rafael Fernandes Experimental Farm (50 3' 37' S; 37o 23' 50" W; $72 \mathrm{~m}$ ), belonging to Universidade Federal Rural do Semi-Árido (UFERSA), located in the rural area of Mossoró, RN, Brazil.

The climate of the region, according to the Köppen's climate classification, is BSwh', with an average temperature of $27.2^{\circ} \mathrm{C}$ and average annual rainfall of $766 \mathrm{~mm}$ (Borges et al., 2015).

The soil of the experimental area was classified as Oxisol with sandy texture. Two months before the installation of the experiments, soil samples were collected at 0-20 cm depth and characterized physically and chemically (Table 1 ).

The soil was prepared conventionally, with one plowing and one harrowing, and chemically corrected with dolomitic limestone (950 kg ha-1 and $526.4 \mathrm{~kg} \mathrm{ha}^{-1}$ in the 2016 and 2017 seasons, respectively), two months prior to sowing (Ribeiro et al., 1999). Phosphorus was supplied as a single superphosphate $\left(18 \% \mathrm{P}_{2} \mathrm{O}_{5}\right)$, manually applied $\left(100 \mathrm{~kg} \mathrm{ha}^{-1}\right.$ of $\mathrm{P}_{2} \mathrm{O}_{5}$ in the 2016 and 2017 seasons) in the sowing hole, below the seeds (Pedroso Neto et al., 1999). Potassium, in the form of $\mathrm{KCl}$ $\left(58 \% \mathrm{~K}_{2} \mathrm{O}\right)$, was applied ( $130 \mathrm{~kg} \mathrm{ha}^{-1} \mathrm{~K}_{2} \mathrm{O}$ in the 2016 and 2017 seasons) through irrigation water and split into four equal portions together with the nitrogen $(\mathrm{N})$ doses (Pedroso Neto et al., 1999). Micronutrients were supplied by a commercial formulation (Rexolin ${ }^{\otimes} \mathrm{BRA}$ ) containing $2.1 \% \mathrm{~B}, 0.36 \% \mathrm{Cu}$, $2.66 \% \mathrm{Fe}, 2.48 \% \mathrm{Mn}, 0.036 \% \mathrm{Mo}$ and $3.38 \% \mathrm{Zn}$, in the dose of $1 \mathrm{~kg} \mathrm{ha}^{-1}$, upon the appearance of flower buds, through irrigation water (Pedroso Neto et al., 1999).

Irrigation was applied through a localized drip system, with emitters spaced every twenty centimeters and with flow rate of $1.5 \mathrm{~L} \mathrm{~h}^{-1}$. The applied water depth was based on the daily crop evapotranspiration and calculated according to Allen et al. (1998).

Meteorological data (minimum and maximum daily air temperatures, rainfall, wind speed and solar radiation) were collected from the automatic weather station belonging to the National Institute of Meteorology (INMET) located in the municipality of Mossoró, RN (4 54' 14” S; 37² 22’ 09” W; 29 m) and are presented in Figure 1.

The experimental design was in randomized blocks with split plots and four replicates. Nitrogen doses were allocated in the main plots and the colored cotton cultivars were allocated in the subplots. The experimental units had dimensions of $2.8 \times 3.8 \mathrm{~m}$, with four plant rows of $3.8 \mathrm{~m}$ length, considering two central rows as the usable area, totaling $10.64 \mathrm{~m}^{2}$.

The $\mathrm{N}$ doses used were: $0,50,100,150$ and $200 \mathrm{~kg} \mathrm{ha}^{-1}$, in the form of urea $(45 \% \mathrm{~N})$ and supplied to plants by irrigation

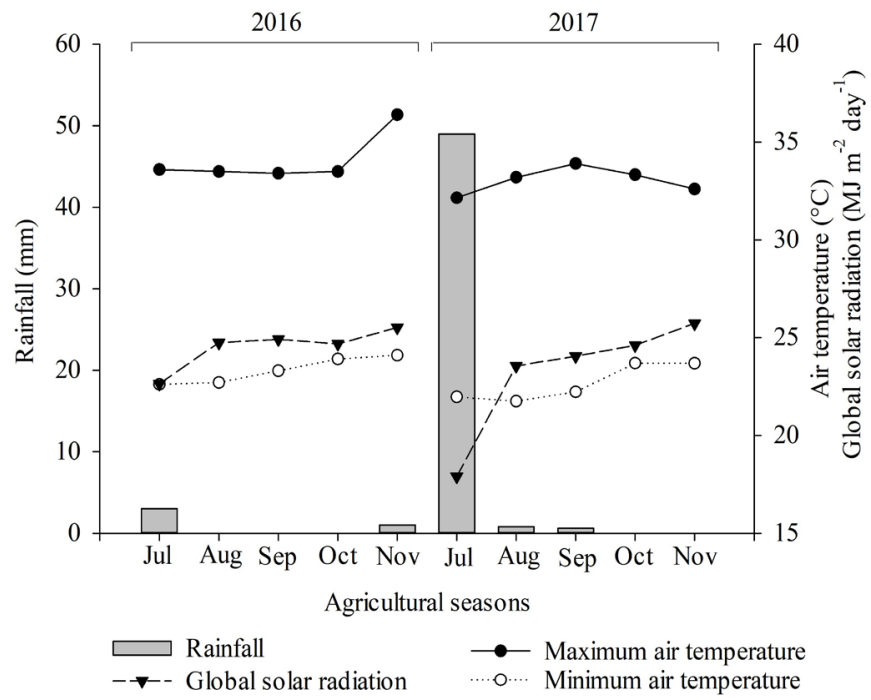

Figure 1. Rainfall, minimum and maximum air temperatures $\left({ }^{\circ} \mathrm{C}\right)$ and global solar radiation incident on the surface $(\mathrm{Rg}$,

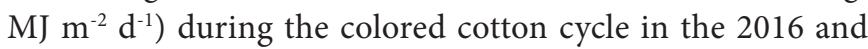
2017 seasons

Table 1. Physicochemical characterization of the soil of the experimental area in the 2016 and 2017 seasons

\begin{tabular}{|c|c|c|c|c|c|c|c|c|c|c|c|c|}
\hline \multirow{2}{*}{ Season } & Sand & Silt & Clay & \multirow{2}{*}{$\begin{array}{c}\mathrm{pH} \\
\text { water }\end{array}$} & \multirow{2}{*}{$\begin{array}{c}\mathrm{OM} \\
\left(\mathrm{g} \mathrm{kg}^{-1}\right)\end{array}$} & $\mathbf{P}$ & K & $\mathrm{Na}$ & $\mathrm{Ca}$ & $\mathrm{Mg}$ & Al & $\mathrm{H}+\mathrm{Al}$ \\
\hline & & $\left(\mathrm{g} \mathrm{kg}^{-1}\right.$ & & & & \multicolumn{3}{|c|}{$\frac{n}{\left(m g d m^{-3}\right)}$} & \multicolumn{4}{|c|}{$\left(\mathrm{cmol}_{\mathrm{c}} \mathrm{dm}^{-3}\right)$} \\
\hline 2016 & 900 & 20 & 80 & 4.40 & 7.52 & 3.0 & 27.1 & 8.0 & 0.40 & 0.30 & 0.15 & 1.49 \\
\hline 2017 & 880 & 20 & 100 & 5.00 & 4.38 & 1.9 & 32.4 & 1.6 & 1.40 & 0.70 & 0.00 & 1.98 \\
\hline
\end{tabular}

OM - Organic matter 
water. Each dose was split into four equal portions, applied at emergence, when plants had three true leaves, at the appearance of the floral bud and at the beginning of flowering.

The colored cotton cultivars used were BRS Verde (green fiber), BRS Rubi and BRS Safira (reddish fiber) and BRS Topázio (light brown fiber).

Sowing was performed on $06 / 07 / 16$ ( $1^{\text {st }}$ season) and $26 / 07 / 17$ ( $^{\text {nd }}$ season$)$, by manually placing three seeds per hole, at a depth of 3 to $5 \mathrm{~cm}$. Emergence occurred on 10/07/16 and $30 / 07 / 17$, respectively. The spacing used was $0.70 \times 0.20 \mathrm{~m}$, between rows and between plants, respectively.

Thinning was performed when the plants produced three true leaves, by manually uprooting excess plants, leaving only one plant per hole. Phytosanitary management was performed according to the need, keeping the plants free of weeds, pests and diseases.

Harvest was performed manually when the bolls of the lower half of the plant were open, approximately 100 days after emergence (DAE), and lasted until the opening of all bolls. All plants from the usable area were harvested and the bolls were evaluated in the Plant Science Laboratories of UFERSA, determining the production components.

The characteristics evaluated were: seed cotton yield (SCY), determined by weighing the fiber with the seed on a digital scale, converted to $\mathrm{kg} \mathrm{ha}^{-1}$; cotton fiber yield (CFY), determined by multiplying SCY (in $\mathrm{kg} \mathrm{ha}^{-1}$ ) by the percentage of fiber (obtained in the laboratory of Embrapa Cotton), expressed in $\mathrm{kg} \mathrm{ha}^{-1}$; leaf $\mathrm{N}$ concentration (LNC), determined according to the methodology described by Malavolta et al. (1997), collecting the diagnostic leaf at 56 DAE in the 2016 season and at $64 \mathrm{DAE}$ in the 2017 season.

The technical dose of $\mathrm{N}$ (TD) was determined by the derivative of the equations between yield and $\mathrm{N}$ doses described by the quadratic model. The economical dose of $\mathrm{N}$ (ED) was calculated according to Natale et al. (2011) and Resende \& Costa (2014) for both seed cotton and cotton fiber. Therefore, the average prices paid to the producer per $\mathrm{kg}$ of seed cotton were considered to be R $\$ 3.00$ for BRS Verde and R\$2.50 for the other cultivars. For cotton fiber, a price of $\mathrm{R} \$ 12.00$ was considered for BRS Verde and a price of R $\$ 8.00$ was considered for other colored cultivars.

The cost of the $\mathrm{kg}$ of $\mathrm{N}$, considering urea as the source, was R\$3.55 in 2016 and R\$ 3.72 in 2017. Due to variations in currency, the exchange ratio was used instead of currency. Thus, the 'currency' used in the calculations was cotton (seed cotton or fiber), considering the following exchange ratio: $\mathrm{kg}$ of $\mathrm{N}$ applied/kg of cotton commercialized (seed cotton or fiber).

Thus, the ED was calculated based on the derivative of the regression equation between the $\mathrm{N}$ doses applied and cotton production (seed cotton and fiber), making it equal to the exchange ratio, that is:

$$
\frac{d y}{d x}=b+2 a x=\text { exchange ratio }
$$

The most economical dose (X') was then calculated by Eq. 2. For comparison, the dollar was quoted at $\mathrm{R} \$ 3.39$ in June 2016 and at R\$ 3.11 in June 2017.

$$
X^{\prime}=\frac{b-\text { exchange ratio }}{2(-a)}
$$

The increase in production resulting from $\mathrm{N}$ fertilization was determined by Eq. 3. The cost of $\mathrm{N}$ and profit were calculated by Eqs. 4 and 5, respectively.

$$
\begin{aligned}
\text { Increase in production } & =\text { cotton yield with the ED - } \\
& - \text { yield at the zero dose }
\end{aligned}
$$

$$
\text { Cost of } \mathrm{N}=\frac{(\mathrm{ED} \cdot \text { price of } \mathrm{kg} \text { of } \mathrm{N})}{\text { cotton selling price }}
$$

$$
\text { Profit }=\text { increase in production }- \text { cost of } \mathrm{N}
$$

The data were subjected to analysis of variance in each agricultural season and then analyzed jointly. When there was significant effect were submitted polynomial regression analysis.

\section{Results AND Discussion}

Nitrogen concentration in the leaf tissue was influenced by the interaction between the factors studied. In the two agricultural seasons, the increase in $\mathrm{N}$ doses applied caused linear increments in leaf $\mathrm{N}$ concentrations in all cotton cultivars (Figures $2 \mathrm{~A}$ and $\mathrm{B}$ ).

The absence of $\mathrm{N}$ fertilization led to the lowest leaf $\mathrm{N}$ concentrations in the two agricultural seasons. The average maximum concentrations were $43 \mathrm{~g} \mathrm{~kg}^{-1}$ in the 2016 season (Figure 2A) and $40.6 \mathrm{~g} \mathrm{~kg}^{-1}$ in the 2017 season (Figure 2B), with $200 \mathrm{~kg} \mathrm{ha}^{-1}$ of $\mathrm{N}$.

Seed cotton yield in the 2016 season, as a function of $\mathrm{N}$ doses, was described by the quadratic regression model for cultivar BRS Topázio and a linear model for BRS Rubi, BRS Safira and BRS Verde (Figure 3A). The maximum yields obtained were $4,104.58 \mathrm{~kg} \mathrm{ha}^{-1}$ for BRS Topázio at the $\mathrm{N}$ dose of $142 \mathrm{~kg} \mathrm{ha}^{-1}$ and 3,260.75, 4,097.75 and 3,419.25 $\mathrm{kg} \mathrm{ha}^{-1}$, respectively, for the cultivars BRS Rubi, BRS Safira and BRS Verde, at the $\mathrm{N}$ dose of $200 \mathrm{~kg} \mathrm{ha}^{-1}$.

In the 2017 season, seed cotton yield was described by a quadratic model for all cultivars (Figure $3 \mathrm{~B}$ ). The maximum yields obtained were $3,482.9 \mathrm{~kg} \mathrm{ha}^{-1}$ for BRS Topázio at the $\mathrm{N}$ dose of $175 \mathrm{~kg} \mathrm{ha}^{-1}, 2,644.18 \mathrm{~kg} \mathrm{ha}^{-1}$ for BRS Rubi at the N dose of $149 \mathrm{~kg} \mathrm{ha}^{-1}, 2,979.65 \mathrm{~kg} \mathrm{ha}^{-1}$ for BRS Safira at the N dose of $176 \mathrm{~kg} \mathrm{ha}^{-1}$, and $2,750.48 \mathrm{~kg} \mathrm{ha}^{-1}$ for BRS Verde at the $\mathrm{N}$ dose of $154 \mathrm{~kg} \mathrm{ha}^{-1}$.

Cotton fiber yield in the 2016 season, as a function of $\mathrm{N}$ doses, was described by a quadratic regression model for the cultivar BRS Topázio and a linear model for BRS Rubi, BRS Safira and BRS Verde (Figure 3C). The maximum yields obtained were $1,913.06 \mathrm{~kg} \mathrm{ha}^{-1}$ for BRS Topázio at the $\mathrm{N}$ dose of $141 \mathrm{~kg} \mathrm{ha}^{-1}$ and 1,275.75, 1,542.0 and $963.5 \mathrm{~kg} \mathrm{ha}^{-1}$, respectively, for the cultivars BRS Rubi, BRS Safira and BRS Verde at the N dose of $200 \mathrm{~kg} \mathrm{ha}^{-1}$.

In the 2017 season, the fit for cotton fiber yield was quadratic for BRS Topázio, BRS Rubi and BRS Safira and linear for BRS Verde (Figure 3D). The maximum yields obtained 

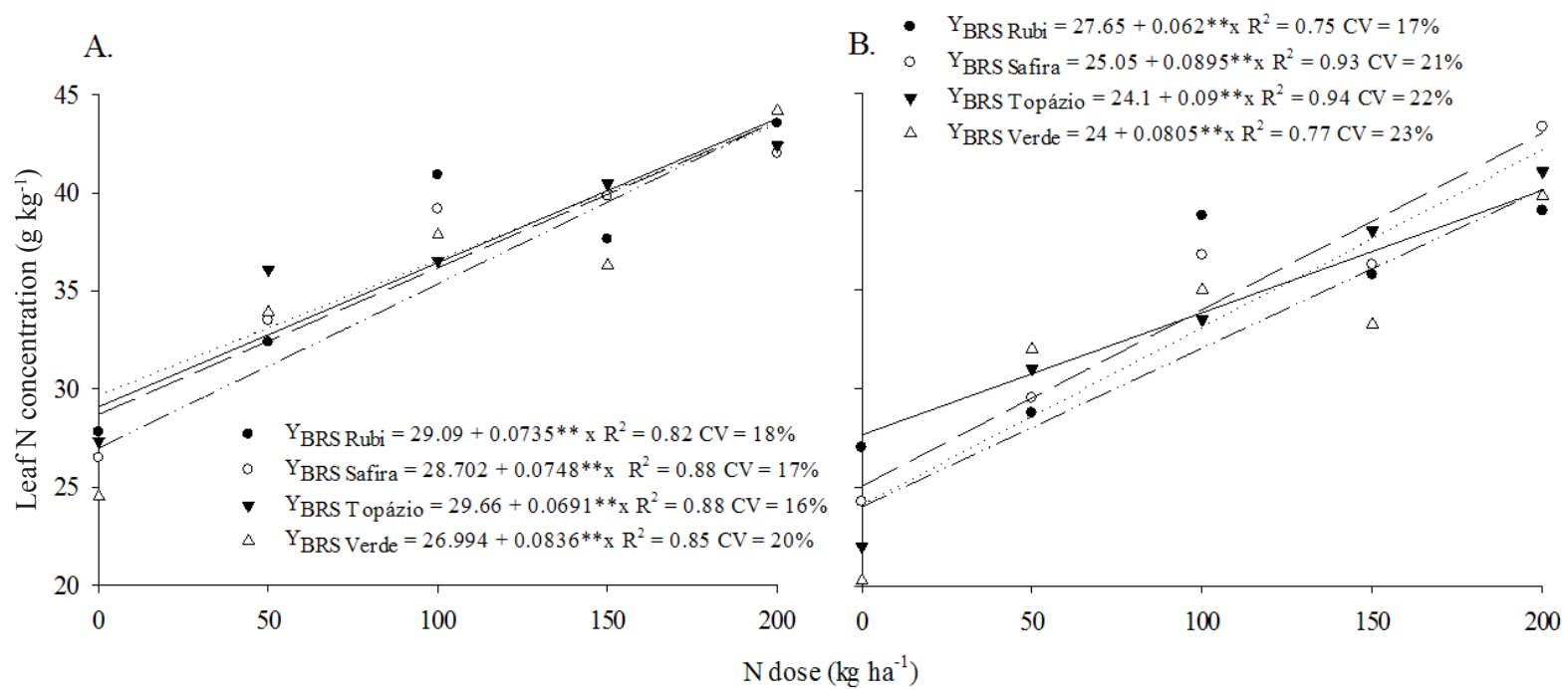

** - Significant at $\mathrm{p} \leq 0.01$ by $\mathrm{F}$ test; $\mathrm{R}^{2}$ - Coefficient of determination; $\mathrm{CV}$ - Coefficient of variation

Figure 2. Nitrogen concentration in leaf tissue of naturally colored cotton cultivars and as function of nitrogen doses applied in two agricultural seasons, 2016 (A) and 2017 (B)
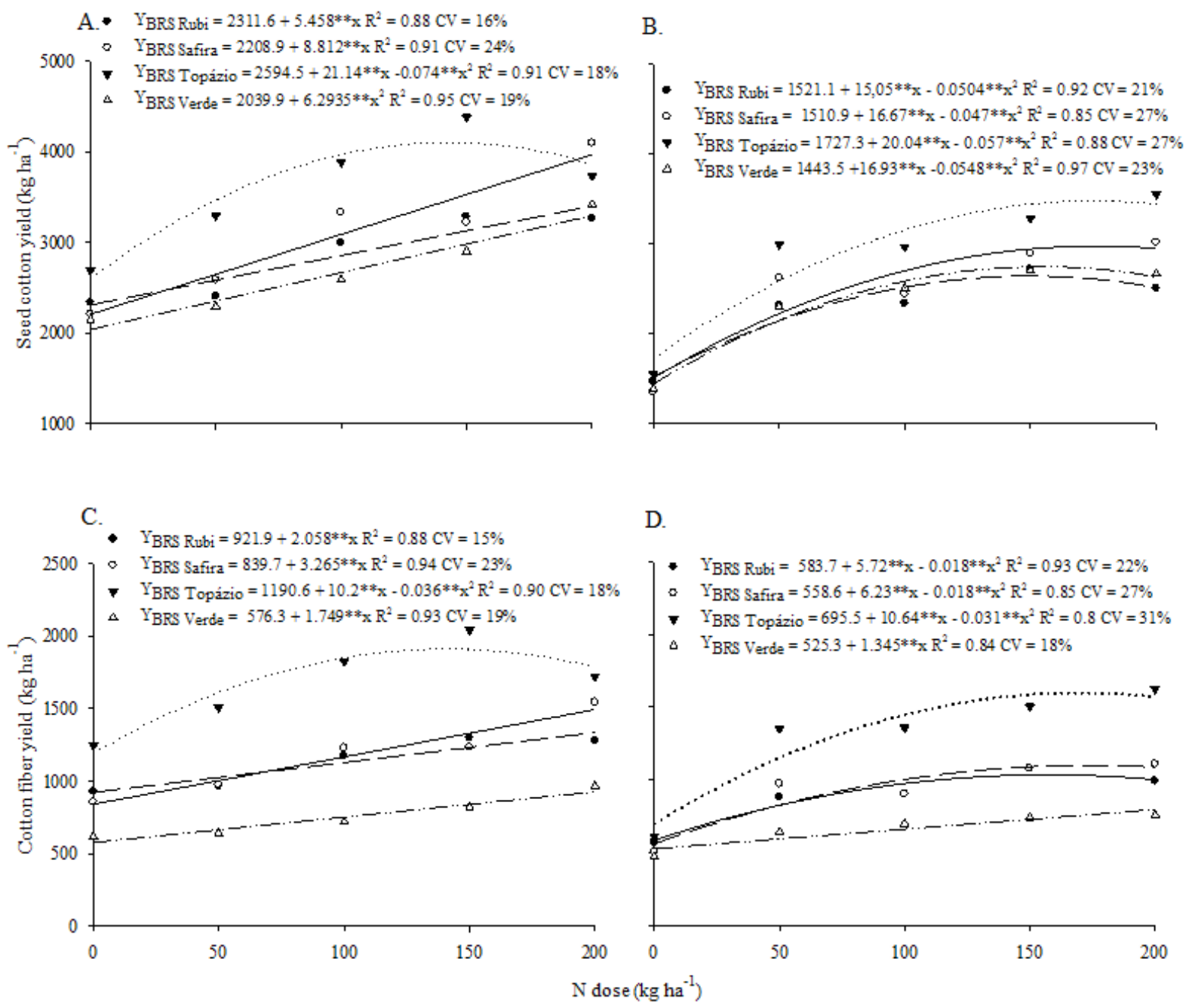

** - Significant at $\mathrm{p} \leq 0.01$ by the $\mathrm{F}$ test; $\mathrm{R}^{2}$ - Coefficient of determination; $\mathrm{CV}$ - Coefficient of variation

Figure 3. Seed cotton yield (A and B) and cotton fiber yield (C and D) of naturally colored cotton cultivars as function of nitrogen doses in two agricultural seasons, 2016 (A and C) and 2017 (B and D)

were $1,608.16 \mathrm{~kg} \mathrm{ha}^{-1}$ for BRS Topázio at the $\mathrm{N}$ dose of $171 \mathrm{~kg} \mathrm{ha}^{-1}$, $1,037.48 \mathrm{~kg} \mathrm{ha}^{-1}$ for BRS Rubi at the $\mathrm{N}$ dose of $158 \mathrm{~kg} \mathrm{ha}^{-1}$, $1,098.18 \mathrm{~kg} \mathrm{ha}^{-1}$ for BRS Safira at the $\mathrm{N}$ dose of $173 \mathrm{~kg} \mathrm{ha}^{-1}$ and $756.25 \mathrm{~kg} \mathrm{ha}^{-1}$ for BRS Verde at the $\mathrm{N}$ dose of $200 \mathrm{~kg} \mathrm{ha}^{-1}$.
The economical dose of $\mathrm{N}$ for seed cotton was calculated using the regression equation of Figure $3 \mathrm{~A}$ for the cultivar BRS Topázio $\left(\mathrm{Y}=2,594.5+21.142 \mathrm{x}-0.074 \mathrm{x}^{2}\right), \mathrm{Xx}^{\prime}=(21.142$ $-1.42) / 2 \times 0.074=133.2 \mathrm{~kg} \mathrm{ha}^{-1}$. 
The increase in production, resulting from $\mathrm{N}$ fertilization, was determined by: cotton yield with ED - yield at zero dose of $\mathrm{N}\left(4,097.76-2,594.5=1,503.2 \mathrm{~kg} \mathrm{ha}^{-1}\right.$ seed cotton $)$.

The cost of $\mathrm{N}$, in $\mathrm{kg} \mathrm{ha}^{-1}$ of cotton, was determined by the formula: (ED x price of $\mathrm{N})$ /cotton selling price. Substituting the values leads to: $(133.2 \times 3.55) / 2.50=189.2 \mathrm{~kg} \mathrm{ha}^{-1}$ of cotton.

The profit, from the production of cotton with the use of $\mathrm{N}$ fertilizer, was obtained by: increase in production - cost of nitrogen $\left(1,503.2-189.21=1,314.0 \mathrm{~kg} \mathrm{ha}^{-1}\right.$ of cotton) (Table 2).

The economical dose of $\mathrm{N}$ was calculated for the other cultivars described by a quadratic model, in the two agricultural seasons, for seed cotton and cotton fiber, in addition to the increase in production, cost of nitrogen and the profit obtained from the application of nitrogen fertilizer (Natale et al., 2011; Resende \& Costa, 2014).

Cotton plants that developed in the absence of nitrogen showed low $\mathrm{N}$ concentration in their leaf tissue, well below the contents considered suitable for cotton (Figures 2A and B), which are between 35 and $43 \mathrm{~g} \mathrm{~kg}^{-1}$ of $\mathrm{N}$ according to Ribeiro et al. (1999) and between 39.1 and $43.2 \mathrm{~g} \mathrm{~kg}^{-1}$ of $\mathrm{N}$ according to Kurihara et al. (2013).

The low $\mathrm{N}$ concentration in the leaf tissue, in the absence of $\mathrm{N}$ fertilization, was associated with visual symptoms of deficiency, such as leaf chlorosis, stunted plants, smaller leaf blades and lower number of bolls per plant. These symptoms were also observed in plants subjected to the $\mathrm{N}$ dose of $50 \mathrm{~kg} \mathrm{ha}^{-1}$, but with less intensity. From the $\mathrm{N}$ dose of $100 \mathrm{~kg} \mathrm{ha}^{-1}$, no visual symptoms of $\mathrm{N}$ deficiency were observed; however, chemical analysis of plant tissue showed that plants had $\mathrm{N}$ contents below the ideal for the crop (Figure 2B).

$\mathrm{N}$ doses above $100 \mathrm{~kg} \mathrm{ha}^{-1}$ promoted $\mathrm{N}$ concentrations within the sufficiency zone for all cultivars in the 2016 season. However, in 2017, only at the dose of $200 \mathrm{~kg} \mathrm{ha}^{-1}$ the cultivars showed $\mathrm{N}$ contents considered adequate.

Lower $\mathrm{N}$ concentrations in the leaf tissue in the absence of $\mathrm{N}$ fertilization and at the $\mathrm{N}$ dose of $50 \mathrm{~kg} \mathrm{ha}^{-1}$ are related, in addition to the low $\mathrm{N}$ doses applied, to the low organic matter content in the soil, which is the largest $\mathrm{N}$ source for plants (Ferreira \& Carvalho, 2005; Santos et al., 2018). Thus, when the soil is poor in organic matter, such as that of the experimental area (Table 1), $\mathrm{N}$ fertilization is important for plants to produce satisfactorily and increase yield (Figure 3).

In the 2016 season, the plants had higher $\mathrm{N}$ concentration in the leaf tissue (Figure 2A) and higher yields in seed cotton and cotton fiber (Figures 3A and C). The lower results in 2017
(Figures 2B, 3B and D) may be due to the climatic differences that occurred during the experiment, especially rainfall (Figure 1), which, with greater intensity in 2017, may have leached the $\mathrm{N}$ applied out of the root absorption zone, reducing its absorption by plants, which showed lower leaf $\mathrm{N}$ content. In addition, the soil had lower organic matter content in 2017 (Table 1), supplying less $\mathrm{N}$ for plants.

For some of the cultivars, especially in the 2016 season (Table 2 and Figure 3), it was not possible to determine the $\mathrm{N}$ dose of highest technical efficiency, and thus the economical dose of $\mathrm{N}$, because the doses applied were not sufficient for the cultivars to reach the point of maximum yield, so higher doses need to be tested.

The economical dose of $\mathrm{N}$ was estimated in the 2017 season, except for BRS Verde. It is important to point out that the yields obtained with the economical doses of $\mathrm{N}$ were very similar to the technical doses, representing more than $99 \%$ of the maximum physical yield, which has also been observed by Natale et al. (2011) and Resende \& Costa (2014).

Determining the economical dose of $\mathrm{N}$ is important for saving fertilizer and labor in the application, but without significant losses in cotton yield. For the same cultivars, different economical doses of $\mathrm{N}$ were obtained in the two agricultural seasons, which may be due to differences in climatic conditions (Figure 1) and soil fertility (Table 1) during the two seasons. Higher rainfall in 2017 may have caused losses of ammoniacal $\mathrm{N}$ and thus lower efficiency in $\mathrm{N}$ use by plants (Rochette et al., 2009; Lorensini et al., 2012). Moreover, in the 2017 season, the lower contents of organic matter and phosphorus in the soil may have limited its availability to plants.

The importance of $\mathrm{N}$ fertilization in the yield of naturally colored cotton is evident with the increase in yield (Table 2), which varied from $1,112.2$ to $1,745.9 \mathrm{~kg} \mathrm{ha}^{-1}$ for seed cotton and from 450.7 to $911.2 \mathrm{~kg} \mathrm{ha}^{-1}$ for cotton fiber when compared to treatments without the use of $\mathrm{N}$. These results demonstrate that $\mathrm{N}$ fertilization is advantageous, since the use of $\mathrm{N}$ represented low production cost (Table 2) because, on average, $209.4 \mathrm{~kg} \mathrm{ha}^{-1}$ of cotton were necessary to pay for $\mathrm{N}$ costs in the production of seed cotton and $69.64 \mathrm{~kg} \mathrm{ha}^{-1}$ were necessary to pay for $\mathrm{N}$ costs in the production of fiber.

The low cost of $\mathrm{N}$ compared to the profit achieved with the commercialization of cotton enables the application of $\mathrm{N}$ in colored cotton plantations, because the high yield obtained covers the costs and generate profit for the producer.

Table 2. Economical dose of nitrogen, increase in production, cost of nitrogen, profit and percentage of production in relation to the technical dose for naturally colored cotton subjected to N doses in the agricultural years 2016 and 2017

\begin{tabular}{|c|c|c|c|c|c|c|c|}
\hline & Season & Cultivar & \multirow{2}{*}{$\begin{array}{c}\text { Economical } \\
\left.\text { dose ( } \mathrm{kg} \mathrm{ha}^{-1} \text { of } \mathrm{N}\right)\end{array}$} & $\begin{array}{c}\text { Increase } \\
\text { in production }\end{array}$ & $\begin{array}{c}\text { Cost } \\
\text { of nitrogen } \\
\end{array}$ & Profit & \multirow{2}{*}{$\begin{array}{l}\text { Production } \\
\text { (\%) }\end{array}$} \\
\hline \multirow{6}{*}{$\begin{array}{l}\text { Seed } \\
\text { cotton }\end{array}$} & & & & & & & \\
\hline & 2016 & BRS Topázio & 133.2 & $1,503.2$ & 189.2 & $1,314.0$ & 99.8 \\
\hline & \multirow{4}{*}{2017} & BRS Verde & 143.1 & $1,299.9$ & 177.4 & $1,122.5$ & 99.7 \\
\hline & & BRS Safira & 160.4 & $1,457.0$ & 238.7 & $1,218.2$ & 99.6 \\
\hline & & BRS Rubi & 134.5 & $1,112.2$ & 200.2 & 911.2 & 99.5 \\
\hline & & BRS Topázio & 162.1 & $1,745.9$ & 241.3 & $1,504.5$ & 99.7 \\
\hline \multirow{4}{*}{$\begin{array}{l}\text { Cotton } \\
\text { fiber }\end{array}$} & 2016 & BRS Topázio & 135.5 & 721.1 & 60.1 & 661.0 & 99.9 \\
\hline & \multirow{3}{*}{2017} & BRS Safira & 160.2 & 536.5 & 74.5 & 462.0 & 99.7 \\
\hline & & BRS Rubi & 145.8 & 450.7 & 67.8 & 382.9 & 99.6 \\
\hline & & BRS Topázio & 164.1 & 911.2 & 76.3 & 834.8 & 99.9 \\
\hline
\end{tabular}


The cultivars showed different responses regarding the increase in $\mathrm{N}$ doses applied in the soil, with different economical doses for each cultivar. These results can be justified by their higher or lower efficiency in the absorption and utilization of $\mathrm{N}$ in physiological processes (Araújo et al., 2013; Du et al., 2016). Identifying these differences and indicating an optimal dose for each cultivar reduces production costs while avoiding environmental contamination with excess of N (Ferreira \& Carvalho, 2005; Spiertz, 2010).

The cultivar BRS Topázio showed high yield, with average values for the two seasons of $3,793.74 \mathrm{~kg} \mathrm{ha}^{-1}$ of seed cotton and $1,760.61 \mathrm{~kg} \mathrm{ha}^{-1}$ of cotton fiber, which are similar to that obtained at national level for white fiber cultivars, which according to CONAB (2018) are 4,236 kg ha-1 for seed cotton and $1,683 \mathrm{~kg} \mathrm{ha}^{-1}$ for cotton fiber. With these results, BRS Topázio presents itself as a satisfactory option for large-scale planting because, in addition to high yield, the value paid for the $\mathrm{kg}$ of colored fiber is higher than that paid for the $\mathrm{kg}$ of white cotton.

The best results obtained by the cultivar BRS Topázio can be explained by its genetic superiority for this characteristic, because it derives from the cross of a highly productive white fiber cultivar, Delta Opal, with a colored fiber genotype. BRS Topázio is considered, among the colored fiber cultivars, the one with the best quality and highest fiber yield (Carvalho et al., 2011). The other cultivars, with lower yields, derive from crosses of colored fiber cultivars, with lower selection pressure for traits of quality and fiber yield (Carvalho et al., 2011), thus, with lower response to $\mathrm{N}$ fertilization.

The cultivars BRS Verde, BRS Rubi and BRS Safira did not show very high yields, but have differentiated fiber color, which promotes high added value for the fabric manufactured from the fiber of these cultivars.

\section{Conclusions}

1. Higher yield of naturally colored cotton can be obtained using the economical doses of $140 \mathrm{~kg} \mathrm{ha}^{-1} \mathrm{~N}$ for the cultivars BRS Rubi and BRS Verde, $150 \mathrm{~kg} \mathrm{ha}^{-1} \mathrm{~N}$ for BRS Topázio and $160 \mathrm{~kg} \mathrm{ha}^{-1} \mathrm{~N}$ for BRS Safira.

2. Highest yield was achieved with the cultivar BRS Topázio and the lowest with the cultivar BRS Verde.

\section{Acknowledgments}

To Empresa Brasileira de Pesquisa Agropecuária (EMBRAPA) of Campina Grande, PB, Brazil, for providing colored cotton seeds and for conducting fiber analysis. To the Universidade Federal Rural do Semi-Árido (UFERSA) and to the Graduate Program in Plant Science for the infrastructure support.

This study was carried out with support from Coordenação de Aperfeiçoamento de Pessoal de Nível Superior, Brazil (CAPES) - Financing Code 001.

\section{Literature Cited}

Allen, R. G.; Pereira, L. S.; Raes, D.; Smith, M. Crop evapotranspiration: Guidelines for computing crop water requirements. Rome: FAO, 1998. 300p.
Alves, W. W. A.; Azevedo, C. A. V. de; Dantas Neto, J.; Sousa, J. T. de; Lima, V. L. A. de. Águas residuárias e nitrogênio: Efeito na cultura do algodão marrom. Revista Verde de Agroecologia e Desenvolvimento Sustentável, v.4, p.16-23, 2009.

Araújo, E. de O.; Camacho, M. A.; Vincensi, M. M. Nitrogen use efficiency by cotton varieties. Revista de Ciências Agrárias, v.36, p.10-16, 2013.

Borges, V. P.; Silva, B. B. da; Espínola Sobrinho, J.; Ferreira, R. da C.; Oliveira, A. D. de; Medeiros, J. F. de. Energy balance and evapotranspiration of melon grown with plastic mulch in the Brazilian semiarid region. Scientia Agricola, v.72, p.385-392, 2015. https://doi.org/10.1590/0103-9016-2014-0136

Carvalho, L. P. de; Andrade, F. P. de; Silva Filho, J. L. da. Cultivares de algodão colorido no Brasil. Revista Brasileira de Oleaginosas e Fibrosas, v.15, p.37-44, 2011.

CONAB - Companhia Nacional de Abastecimento. Proposta de preços mínimos - Safra 2013/2014: Produtos da safra de verão. Brasília: CONAB, 2013. 161p.

CONAB - Companhia Nacional de Abastecimento. Acompanhamento da safra brasileira de grãos - Safra 2017/2018. Brasília: CONAB, 2018. 148p.

Devkota, M.; Martius, C.; Lamers, J. P. A.; Sayre, K. D.; Dekota, K. P.; Vlek, P. L. G. Tillage and nitrogen fertilization effects on yield and nitrogen use efficiency of irrigated cotton. Soil \& Tillage Research, v.134, p.72-82, 2013. https://doi.org/10.1016/j.still.2013.07.009

Dong, H.; Kong, X.; Li, W.; Tang, W.; Zhang, D. Effects of plant density and nitrogen and potassium fertilization on cotton yield and uptake of major nutrients in two fields with varying fertility. Field Crops Research, v.119, p.106-113, 2010. https://doi.org/10.1016/j. fcr.2010.06.019

Du, X.; Chen, B.; Zhang, Y.; Zhao, W.; Shen, T.; Zhou, Z.; Meng, Y. Nitrogen use efficiency of cotton (Gossypium hirsutum L.) as influenced by wheat-cotton cropping systems. European Journal of Agronomy, v.75, p.72-79, 2016. https://doi.org/10.1016/j.eja.2016.01.001

Ferreira, G. B.; Carvalho, M. da C. S. Adubação do algodoeiro no Cerrado: Com resultados de pesquisa em Goiás e Bahia. Campina Grande: Embrapa Algodão, 2005. 71p. Documentos, 138.

Kurihara, C. H.; Venegas, V. H. A.; Neves, J. C. L.; Novais, R. F. de; Staut, L. A. Faixas de suficiência para teores foliares de nutrientes em algodão e em soja, definidas em função de índices DRIS. Revista Ceres, v.60, p.412-419, 2013. https://doi.org/10.1590/ S0034-737X2013000300015

Lima, G. S. de; Dias, A. S.; Soares, L. A. dos A.; Gheyi, H. R.; Nobre, R. G.; Souza, L. de P. Growth and yield of colored-fiber cotton grown under salt stress and nitrogen fertilization. Revista Brasileira de Engenharia Agrícola e Ambiental, v.21, p.415-420, 2017. https:// doi.org/10.1590/1807-1929/agriambi.v21n6p415-420

Lima, M. M. de; Azevedo, C. V. de; Beltrão, N. E. de M.; Lima, V. L. A. de; Nascimento, M. B. H. do; Figueirêdo, I. C. de M. Níveis de adubação nitrogenada e bioestimulante na produção e qualidade do algodão BRS Verde. Revista Brasileira de Engenharia Agrícola e Ambiental, v.10, p.619-623, 2006. https://doi.org/10.1590/S1415-43662006000300012

Lorensini, F. Ceretta, C. A.; Girotto, E.; Cerini, J. B.; Lourenzi, C. R.; Conti, L. de; Trindade, M. M.; Melo, G. W. de; Brunetto, G. Lixiviação e volatilização de nitrogênio em um Argissolo cultivado com videira submetida à adubação nitrogenada. Ciência Rural, v.42, p.1173-1179, 2012. https://doi.org/10.1590/S0103-84782012005000038

Malavolta, E.; Vitti, G. C.; Oliveira, S. A. Avaliação do estado nutricional das plantas: Princípios e aplicações. 2.ed. Piracicaba: POTAFOS, 1997. 319p. 
Natale, W.; Rozane, D. E.; Prado, R. de M.; Romualdo, L. M.; Souza, H. A.; Hernandes, A. Dose econômica de calcário na produtividade de caramboleiras. Revista Brasileira de Fruticultura, v.33, p.12941299, 2011. https://doi.org/10.1590/S0100-29452011000400030

Pedroso Neto, J. C.; Fallieri, J.; Silva, N. M.; Laca, J. B. Algodão. In: Ribeiro, A. C.; Guimarães, P. T. G.; Alvarez V., V. H. (ed.) Recomendações para o uso de corretivos e fertilizantes em Minas Gerais: $5^{\text {a }}$. Aproximação. Comissão de Fertilidade do solo do estado de Minas Gerais, CFSEMG, 1999. p.278-279.

Peixoto, F.; Marinho, G.; Rodrigues, K. Corantes têxteis: Uma revisão. Holos, v.5, p.98-106, 2013. https://doi.org/10.15628/holos.2013.1239

Queiroga, V. de P.; Carvalho, L. P. de; Cardoso, G. D. Cultivo do algodão colorido orgânico na região semi-árido do nordeste brasileiro. Campina Grande: Embrapa Algodão, 2008. 50p. Documentos, 204.

Reis Junior, R. dos A.; Silva, D. R. G.; Ávila, F. W.; Ávila, P. A. de; Soares, D. de A.; Faquin, V. Productivity and agronomic efficiency of cotton plants in response to nitrogen and sulfur supply. Revista Brasileira de Ciências Agrárias, v.7, p.555-561, 2012. https://doi. org/10.5039/agraria.v7i4a1514

Resende, G. M.; Costa, N. D. Dose econômica de nitrogênio na produtividade e armazenamento de cultivares de cebola. Horticultura Brasileira, v.32, p.357-362, 2014. https://doi. org/10.1590/S0102-05362014000300019
Ribeiro, A. C.; Guimarães, P. T. G.; Alvarez V., V. H. Recomendações para o uso de corretivos e fertilizantes em Minas Gerais: $5^{\text {a }}$ aproximação. Belo Horizonte: Comissão de Fertilidade do Solo do Estado de Minas Gerais, 1999. 359p.

Rochette, P.; Angers, D. A.; Chantigny, M. H.; MacDonald, J. D.; Gasser, M.-O.; Bertrand, N. Reducing ammonia volatilization in a no-till soil by incorporating urea and pig slurry in shallow bands. Nutrient Cycling in Agroecosystems, v.84, p.71-80, 2009. https://doi.org/10.1007/s10705-008-9227-6

Santos, M. G. dos; Ribeiro, R. M. P.; Albuquerque, J. R. T. de; Lins, H. A.; Barros Júnior, A. P.; Bezerra Neto, F.; Silveira, L. M. da; Soares, E. B.; Souza, A. R. E. de. Production performance of sesame cultivars under different nitrogen rates in two crops in the Brazilian semi-arid region. Industrial Crops and Products, v.124, p.1-8, 2018. https://doi.org/10.1016/j. indcrop.2018.07.015

Spiertz, J. H. J. Nitrogen, sustainable agriculture and food security: A review. Agronomy for Sustainable Development, v.30, p.43-55, 2010. https://doi.org/10.1051/agro:2008064

Stamatiadis, S.; Tsadilas, C.; Samaras, V.; Schepers, J. S.; Eskridge, K. Nitrogen uptake and $\mathrm{N}$-use efficiency of Mediterranean cotton under varied deficit irrigation and $\mathrm{N}$ fertilization. European Journal of Agronomy, v.73, p.144-151, 2016. https://doi. org/10.1016/j.eja.2015.11.013 